\begin{tabular}{lcl}
\hline Bentham OPEN & Open Medicine Journal \\
CrossMark & Content list available at: www.benthamopen.com/MEDJ/ & $\begin{array}{l}\text { Open } \\
\text { Medicine } \\
\text { lournal }\end{array}$ \\
\hline
\end{tabular}

\title{
EDITORIAL
}

\section{Introductory Commentary to Special Issue: Inter-professional Approaches in Forensic Practice}

The field of forensic science applies science to the field of law often within a public format. Forensic scientists collect, preserve, and analyze scientific evidence during the course of an investigation, which often occurs while examining and then treating a patient in an acute or primary care setting.

Nurses and physicians who are forensic scientists apply forensic principles to the treatment of trauma, abuse, and neglect to those who are living and dead. This issue developed from a commitment to address many facets of forensic practice highlight some of the complex issues encountered.

The eight articles in this issue written by nurses, physicians, and attorneys reflect diverse areas of interest in the field of forensic science and deal with many facets of forensic science such as education of clinician, specific types of abuse of adults and children to the ethical issues faced in the use of postmortem specimens used in tissue research and to aspects of what a medicolegal death investigation involves and how to make the processes better. The topics are diverse and relevant to today's forensic practitioner.

The article on human trafficking comes from the perspective of attorneys who are experts in the legal system and deal with the victims as well. The article shows how local and national policies affect what happens to those who are the victims as well as the perpetrators - and identifies gaps within the current policies while offering solutions to fill the gap.

There are four articles that address clinical aspects of abuse (elder, sexual and medical abuse, otherwise known as Munchausen syndrome, and identification of anatomy findings that are essential in identifying child sexual abuse). Each article addresses approaches for clinicians to improve care to victims through the identification of a problem, and then offers ways to treat the identified problem.

Each medically based article deals with various aspects of identification of problem, collection of evidence, documentation of data in a way that can be used for legal proceedings, and treatment of the condition brought on by trauma or abuse.

The article on online programs in Forensic Nursing Science describes a master's level program to educate nurses who want to develop more expertise in the area of forensic nursing. Forensic nursing is a burgeoning field where nurses learn the complexities of forensic science that intersects with nursing practice in the delivery of healthcare in a complex system.

Two articles discuss the practical aspects encountered within the medicolegal death investigation setting. The first article describes the development and implementation of case management system and how case management processes can be adapted to improve essential outcomes.

The second article captures the ethical aspects of using postmortem tissues for the purpose of research. The article highlights how a systemic approach can facilitate tissue research.

The purpose of this issue is to offer the reader a wide range of issues that are all part of forensic practice. The readers of each article should gain a broader perspective of the varied ways in which nurses and physicians work to strengthen all areas of forensic science. 
Finally, we wish to thank our colleagues who shared their knowledge and expertise about the practical aspects of forensic science.

Stacy A. Drake

The University of Texas Health Science Center at Houston School of Nursing Department of Acute and Continuing Education

6901 Bertner Ave., \#622

Houston, TX 77030

USA

E-mail: Stacy.A.Drake@uth.tmc.edu

Eileen R. Giardino

The University of Texas School of Nursing at Houston

Department of Family Nursing

6901 Bertner Avenue

Houston, TX 77030

USA

E-mail: Eileen.R.Giardino@uth.tmc.edu

Angelo P. Giardino

Baylor College of Medicine and Texas Children's Hospital 6621 Fannin, A2210 Houston

TX 77030

USA

E-mail: apgiardi@texaschildrens.org

(C) Angelo P. Giardino; Licensee Bentham Open

This is an open access article licensed under the terms of the Creative Commons Attribution-Non-Commercial 4.0 International Public License (CC BY-NC 4.0) (https://creativecommons.org/licenses/by-nc/4.0/legalcode), which permits unrestricted, non-commercial use, distribution and reproduction in any medium, provided the work is properly cited. 